\title{
THE AUGOCHLORA-LIKE DIALICTUS FROM GUATEMALA AND SOUTHERN MÉXICO (HYMENOPTERA: HALICTIDAE)
}

\author{
Michael S. ENGEL ${ }^{1}$, Ismael A. HinOJOSA-DÍAZ1 \\ and Olivia YÁÑEZ-ORDóÑEZ ${ }^{2}$ \\ ${ }^{1}$ Division of Entomology, Natural History Museum, \\ and Department of Ecology \& Evolutionary Biology, 1501 Crestline Drive-Suite \#140, \\ University of Kansas, Lawrence, Kansas 66049-2811, UNITED STATES \\ 2 Museo de Zoología "Alfonso L. Herrera”, Departamento de Biología Evolutiva, \\ Facultad de Ciencias, Universidad Nacional Autónoma de México, Apdo. postal 70-399, \\ CP 04510 México D.F., MÉXICO
}

\section{RESUMEN}

Se describen e ilustran cuatro especies de abejas provenientes del sur de México y norte de Guatemala, todas incluidas en el género Lasioglossum, subgénero Dialictus, este último significativamente diverso, conociéndose 29 especies para México (si bien existen muchas más en el país). En contraste con la mayoría de las especies de Dialictus, las aquí descritas poseen integumento azul metálico brillante (por lo cual fueron descritas originalmente en el género Augochlora) y puntuación densa y fuerte, lo que les confiere aspecto de abejas parásitas o avispas de la familia Chrysididae. Lasioglossum (Dialictus) cyanorugosum sp. nov., L. (D.) oaxacacola sp. nov., L. (D.) verapaz sp. nov., y L. (D.) aurora (Smith) comb. nov., son descritas, ilustradas y comparadas con otras especies de Dialictus. Se presenta una clave para el "grupo de especies aurora".

Palabras Clave: taxonomía, abejas del sudor, Halictinae, Halictini, Anthophila, Apoidea, Mesoamérica.

\begin{abstract}
Four remarkable bee species are described and illustrated from southern México and northern Guatemala, all of the genus Lasioglossum and in the diverse subgenus Dialictus, previously documented by 29 species throughout México (although many more occur in the country). Uncommon for most Dialictus, the species treated herein are brilliant metallic blue (hence the reason the first species was originally described in the genus Augochlora) and coarsely and densely punctured, resembling to some extent parasitic bees or chrysidid wasps. Lasioglossum (Dialictus) cyanorugosum sp. nov., L. (D.) oaxacacola sp. nov., L. (D.) verapaz sp. nov., and L. (D.) aurora (Smith) comb. nov., are described, illustrated, and compared with other Dialictus species. A key to the "aurora group" of species is provided.
\end{abstract}

Key Words: taxonomy, sweat bees, Halictinae, Halictini, Anthophila, Apoidea, Mesoamerica. 
Engel et al.: The Aurora Group of Lasioglossum (Dialictus)

\section{INTRODUCTION}

Since 1994 one of us (MSE) has been aware of two enigmatic species of the diverse bee genus Lasioglossum subgenus Dialictus (Halictinae: Halictini) occurring in southern México - one described more than a century ago as a species of the augochlorine bee genus Augochlora, the other a new species. Unlike most other Dialictus these species are a deep and brilliant metallic blue in coloration and with a brilliant metallic gold or blue metasoma (Figs. 1-3). In addition, the species have dense and coarse punctation throughout the head and mesosoma, resembling in this respect parasitic species but possessing the full complement of pollen-collecting apparatuses. Like all other Lasioglossum the distal wing venation is weakened, particularly 1rs-m, 2rs-m, and $2 \mathrm{~m}-\mathrm{cu}$ as is typical of Dialictus (Fig. 4). More recently two additional new species were recognized prompting this study, one among material of the previously unnamed Mexican species, while the other was identified from a female collected in northern Guatemala. Together these species form a distinctive group within Dialictus (the "aurora species group"), diagnosable by the aforementioned attributes. Previously 29 species of Dialictus have been recorded from Mexico, and 81 for Lasioglossum it is entirety (Ayala et al. 1996, HinojosaDíaz 2003, McGinley 2003), making it one of the four most diverse genera in the country. This diversity will assuredly grow as the subgenera Dialictus and Evylaeus both include many unaccounted species, a few of which are included herein.

Herein we provide a brief account of this group so as to bring it to the attention of melittologists and to encourage them to seek additional material (particularly males but perhaps also additional species) and information on their biology. In the following account, those species with the most well preserved material are described in detail while the rare species or more incompletely preserved species are described in reference to the more thoroughly understood taxa. Morphological terminology follows that of Engel (2001a) while the format for descriptions follows that widely employed for halictid bees (e.g., Engel 2000, 2001b, Engel et al. 1997, Hinojosa-Díaz 2003, Hinojosa-Díaz \& Engel 2003).

\section{SYSTEMATICS}

\section{Lasioglossum (Dialictus) cyanorugosum sp. nov.}

Figures 2, 4, 6

Diagnosis. Lasioglossum cyanorugosum differs from other species in the aurora group by the blue metasoma (Fig. 2) (distinctly golden in other species). The species is most similar to $L$. aurora (Smith) but differs, aside from metasomal coloration, most notably by the larger mesoscutal areolae ( $c f$. Figs. 5 and 6), the generally smaller body size, and the more strongly angled and protuberant pronotal dorsolateral angle which is distinctly acute (Fig. 6) (more orthogonal in L. aurora: Fig. 5). 


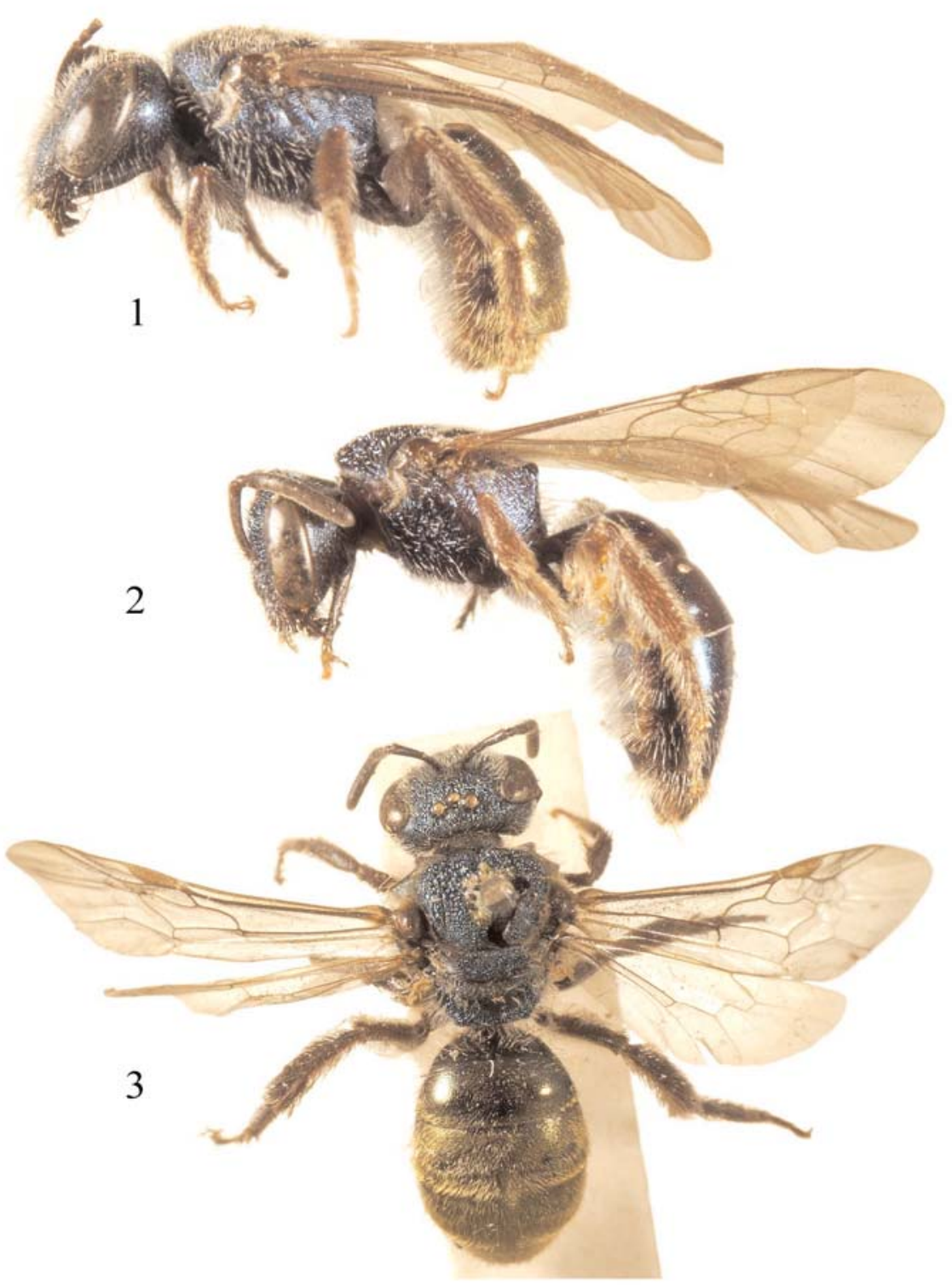

Figuras 1-3.

Representative females of species of the aurora group of Dialictus. 1. Lasioglossum (Dialictus) oaxacacola sp. nov., lateral habitus. 2. L. (D.) cyanorugosum sp. nov., lateral habitus. 3. L. (D.) aurora (Smith), comb. nov., dorsal habitus of holotype. 
Engel et al.: The Aurora Group of Lasioglossum (Dialictus)
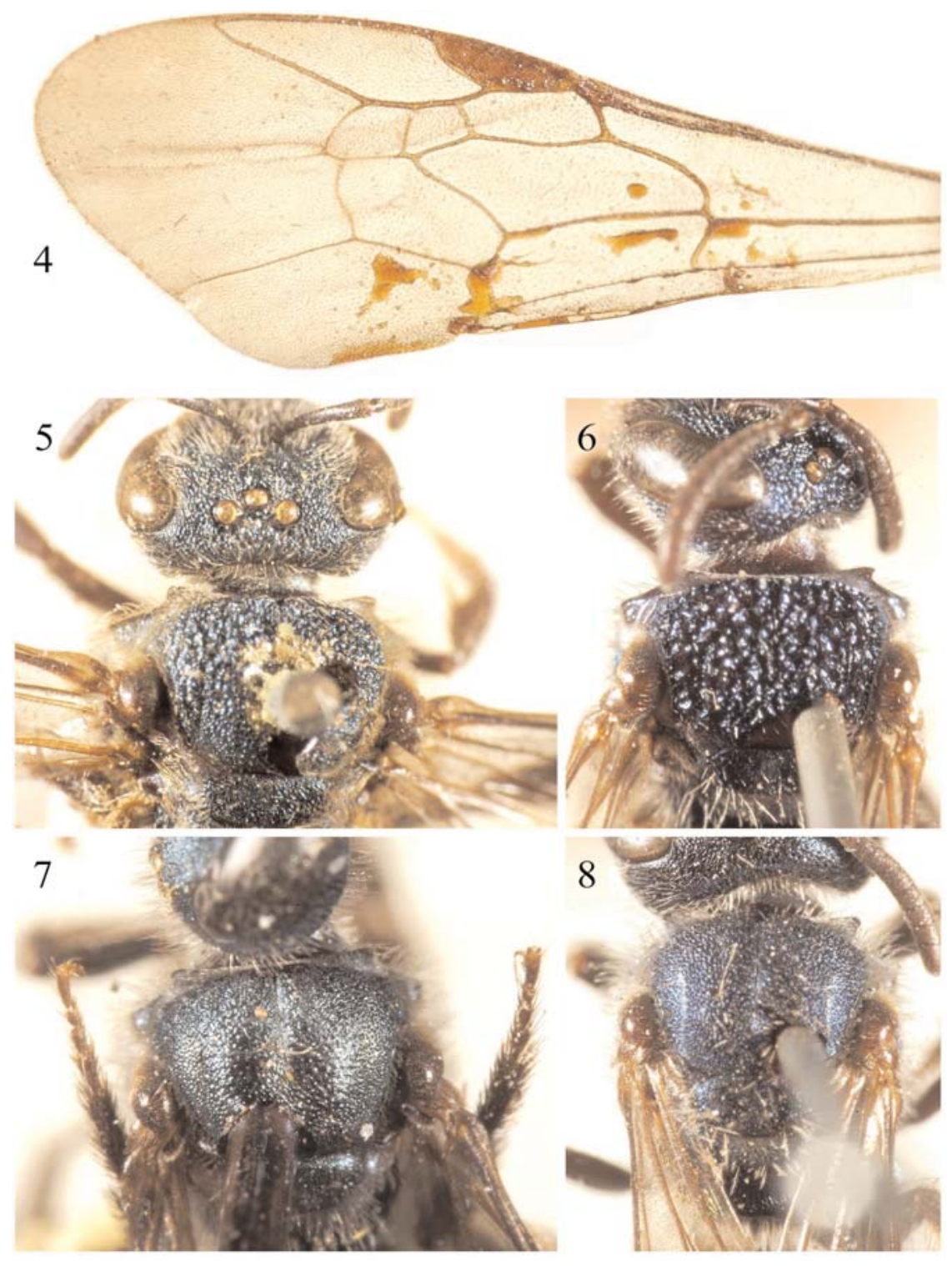

Figuras 4-8.

Species of the aurora group of Dialictus. 4. Forewing venation of Lasioglossum (Dialictus) cyanorugosum sp. nov. 5. Dorsal view of head and anterior mesosoma of holotype female of $L$. $(D$.) aurora (Smith) comb. nov. 6. Dorsal view of head and anterior mesosoma of $L$. (D.) cyanorugosum sp. nov. 7. Dorsal view of posterior head and anterior mesosoma of $L$. (D.) verapaz sp. nov. 8. Dorsal view of posterior head and anterior mesosoma of $L$. (D.) oaxacacola sp. nov. 
Description. Female: Total body length $6.12 \mathrm{~mm}(5.40-7.00 ; \mathrm{n}=31)$; forewing length $5.09 \mathrm{~mm}$ (4.76-5.36; $\mathrm{n}=31)$. Head broader than long, length $1.62 \mathrm{~mm}(1.48-1.76$; $\mathrm{n}=31)$, width $1.85 \mathrm{~mm}$ $(1.72-1.96 ; n=31)$. Mandible with subapical tooth. Lower half of clypeus extending below lower tangent of compound eyes. Epistomal sulcus forming obtuse angle. Compound eyes weakly emarginate above level of antennae; weakly convergent below, upper interorbital distance 1.09 $\mathrm{mm}(1.00-1.12 ; \mathrm{n}=31)$, lower interorbital distance $0.94 \mathrm{~mm}(0.88-1.00 ; \mathrm{n}=31)$; ocelli positioned above upper tangent of compound eyes. Pronotal dorsal ridge strongly carinate to pronotal lobe, dorsolateral angle protuberant and distinctly acutely angled (thereby forming a small dorsolateral projection or tubercle: Fig. 6). Mesoscutal anterior border broadly rounded; intertegular distance $1.31 \mathrm{~mm}(1.16-1.44 ; \mathrm{n}=31)$. Basal area of propodeum approximately as long as scutellum; metanotum approximately two-thirds length of scutellum. Basitibial plate with all borders welldefined; inner metatibial spur pectinate, with three teeth (not including the apical extension of the rachis). Forewing with three submarginal cells; 1rs-m, 2rs-m, and 2m-cu weakened (Fig. 4); hind wing distal hamuli arranged 2-1-2.

Labiomaxillary complex dark brown except palpi amber. Labrum reddish brown, distal process somewhat darker. Mandible reddish-amber, posterior edge black. Clypeus dark brown on apical half, basal half brilliant metallic blue, a thin metallic copper line separating both halves. Antennae uniformly brown except scape and pedicel with thin yellow portions near their apices. Remainder of face brilliant metallic blue with thin reddish-brown paraocular areas; gena and postgena metallic blue. Mesosoma brilliant metallic blue except pronotal lobe darkly amber and pronotum brown with metallic blue highlights; tegula and legs light brown. Wing membrane the color of light parchment (Fig. 4); veins amber except pterostigma, C, and $\mathrm{Sc}+\mathrm{R}$ brown. Metasoma reddish-brown to dark brown with strong metallic blue highlights and a few copper highlights; sterna brown except slightly amber along apical margins.

Clypeus with scattered punctures, those on basal area closer but shallower, integument between punctures minutely imbricate. Scape weakly punctured. Face rugosoareolate, areoles becoming smaller towards vertex and paraocular areas, and weaker on supraclypeal area; gena and postgena strongly striate. Pronotal surface punctate, punctures relatively small, separated by less than a puncture width except on pronotal lobe and dorsolateral angle where integument is finely imbricate. Mesoscutum strongly rugosoareolate, rugae very sharp, areoles deep and large (Fig. 6), about the size of median ocellus, becoming smaller near pronotal lobe. Scutellum rugosoareolate, rugae not as strong as mesoscutum, areoles smaller. Metanotum imbricate, becoming rugose laterally. Pre-episternum, mesepisternum, and hypoepimeral area strongly rugosoareolate; metepisternum horizontally striate on upper two-thirds, lower third rugosoareolate, rugae becoming gradually weaker ventrally. Basal area of propodeum strongly striate longitudinally, posterior edge minutely punctate, punctures separated by about a puncture width, integument otherwise imbricate; lateral and posterior surfaces rugosoareolate, rugae on posterior surface sharper defined, posterior surface bordered by strong carina. Metasoma imbricate with punctures separated by $1-3$ times a puncture width.

Pubescence generally white to pale yellow. Face with short, scattered, whitish setae, minutely branched although appearing simple, becoming shorter toward vertex; gena with setae like those of face; postgena with widely scattered long setae. Pronotal dorsal surface with short setae covering anterior and lower lateral areas; surface along posterior margin connecting dorsolateral 
angles with appressed short setae with several branches arranged in rosettes. Mesoscutum with setae similar to those on face but more scattered; scutellum with some scattered long setae along posterior edge; metanotum covered with appressed, short, branched setae and some scattered, long, minutely-branched setae laterally. Pleura with setae like those laterally on metanotum, becoming more plumose on lower half of mesepisternum. Propodeal lateral surface with numerous long setae bearing long branches; posterior surface with setae on lower two-thirds similar to those laterally on metanotum. First metasomal tergum with long, minutely-branched setae concentrated near base, remainder of terga with scattered short setae on dorsal surface and long setae laterally, except fifth metasomal tergum completely covered by long setae; sternal setae long and distinctly branched, branches becoming shorter on more distal sterna; edges and gradular bases of sterna with medially-interrupted bands of short setae.

Male: Unknown.

Etymology. The specific epithet is a reference to the intense blue coloration and strongly rugose integumental sculpturing of the species.

Type Material. Holotype, [MEXICO] Oaxaca: female, Oaxaca, Crawford [collector]. Collection of L. A. C. M. ex Pomona College, 1967. Deposited at Los Angeles County Museum. Paratypes, 30 females, same data as holotype and deposited in the same institution except two paratypes deposited in the Division of Entomology, University of Kansas Natural History Museum.

\section{Lasioglossum (Dialictus) aurora (Smith) comb. nov.}

Figures 3, 5

Augochlora aurora Smith 1879: 47. Holotype O (NHML), visum. Cockerell 1897: 162. Cockerell 1905a: 357, 362. Cockerell 1912: 317.

Halictus ectypus Vachal 1904: 484. Lectotype $q$ (Paris), non visum. Cockerell 1905b: 91. Synonymy vide Moure \& Hurd (1987).

Dialictus aurora (Smith); Moure \& Hurd 1987: 91.

Diagnosis. Lasioglossum aurora, known only from the holotype collected some time prior to 1875 , can be distinguished from other species in the aurora group by the following combination of traits: pronotal dorsolateral angle orthogonal (Fig. 5), mesoscutum largely rugosoareolate (Fig 5), and metasoma brilliant golden (Fig. 3).

Redescription. As described for L. (D.) cyanorugosum (vide supra) except as follows: Female: Total body length $8.90 \mathrm{~mm}$; forewing length $6.67 \mathrm{~mm}$. Head broader than long, length $2.07 \mathrm{~mm}$, width $2.53 \mathrm{~mm}$. Upper interorbital distance $1.40 \mathrm{~mm}$, lower interorbital distance $1.30 \mathrm{~mm}$. Intertegular distance $2.00 \mathrm{~mm}$. Pronotal dorsolateral angle protuberant, angle approximately orthogonal (Fig. 5).

Mandible reddish-brown, posterior edge black. Clypeus black on apical third, basal twothirds brilliant metallic blue. Antennae uniformly brown. Mesosoma brilliant metallic blue except pronotum brown with strong metallic blue highlights; tegula and legs brown. Metasomal terga brown with strong brilliant golden highlights (Fig. 3); sterna dark brown with scattered metallic blue highlights.

Mesoscutal areolae smaller than those of L. cyanorugosum, width near to or less than onehalf diameter of median ocellus (Fig. 5).

Male: Unknown. 
Type Material. Holotype, Female, "Mex." [MEXICO, no further locality data available]; B.M. Type Hym17a1264. Deposited at the Natural History Museum, London.

\section{Lasioglossum (Dialictus) verapaz sp. nov.}

Figure 7

Diagnosis. This species can be recognized from others of the aurora group by the following combination of features: mesoscutum strongly and densely punctured (rather than rugosoareolate) except medially, pronotal dorsolateral angle approximately orthogonal, metasoma with metallic gold and copper highlights. Lasioglossum verapaz is most similar to L. oaxacacola (vide infra) but differs in that the punctures centrally on the mesoscutal disc are separated by a puncture width and are exceedingly faint on otherwise strongly imbricate integument; the coarse punctures of the mesepisternum gradually blend into dorsoventrally elongate areolae ventrally; and the first metasomal tergum is smooth except for centrally with minute punctures separated by $2-4$ times a puncture width.

Description. Female: Total body length $7.40 \mathrm{~mm}$; forewing length $5.32 \mathrm{~mm}$. Head slightly broader than long, length $1.92 \mathrm{~mm}$, width $2.12 \mathrm{~mm}$. Mandible with weak subapical tooth. Lower half of clypeus extending below lower tangent of compound eyes. Epistomal sulcus forming obtuse angle. Anterior edge of median ocellus slightly below upper tangent of compound eye. Compoud eyes weakly emarginate above level of antennae; weakly convergent below, upper interorbital distance $1.28 \mathrm{~mm}$, lower interorbital distance $1.12 \mathrm{~mm}$. Pronotal dorsolateral angle protuberant, angle approximately orthogonal (Fig. 7). Mesoscutal anterior border broadly rounded. Intertegular distance $1.60 \mathrm{~mm}$. Basal area of propodeum approximately three quarters length of scutellum; metanotum approximately two-thirds length of scutellum. Basitibial plate with all borders well-defined; inner metatibial spur pectinate, with three teeth (not including the apical extension of the rachis). Forewing with three submarginal cells; 1rs-m, 2rs-m, 2m-cu weakened; hind wing with distal hamuli arranged 2-1-2.

Labiomaxillary complex brown to dark brown except palpi light brown. Labrum dark brown. Mandible brown except apex light brown. Clypeus dark brown on apical half, basal half brilliant metallic blue, a thin metallic copper highlight separating both halves. Antenna uniformly brown except pedicel paler distally. Remainder of face brilliant metallic blue with thin copper highlights on brown paraocular areas; gena and postgena metallic blue, postgena becoming metallic copper toward hypostoma. Mesosoma brilliant metallic blue except pronotal lobe brown with metallic blue highlights; tegula and legs brown. Wing membrane the color of light parchment, with scattered faint colored highlights; veins amber except pterostigma, $\mathrm{C}$, and $\mathrm{Sc}+\mathrm{R}$ slightly darker. Metasomal terga brown with olive hue and strong metallic gold and copper highlights; sterna brown with light brown apical margins.

Clypeus and supraclypeal area punctate, punctures separated by 1-2 times a puncture width, becoming slightly bigger and deeper on distal margin of clypeus, integument between punctures strongly imbricate. Scape weakly punctured. Face contiguously punctured, punctures smaller toward vertex and paraocular areas; gena and postgena striate, integument imbricate near hypostomal area. Pronotal surface punctate along posterior margin connecting dorsolateral angles, lateral median areas contiguously punctate becoming slightly striate on lower sides, otherwise imbricate; dorsolateral angle imbricate with some scattered punctures. 
Mesoscutum contiguously and strongly punctured as on face except central disc strongly imbricate with faint (nearly indistinct anteriorly) punctures separated by a puncture width; scutellum contiguously punctured, punctures slighter smaller and shallower than those on mesoscutum; metanotum contiguously punctured, punctures considerably smaller and shallower than those on scutellum, posterior third imbricate. Pre-episternum and mesepisternum coarsely and contiguously punctured on upper half, punctures blending into dorsoventrally elongate areolae on ventral half and on venter; hypoepimeral area coarsely and contiguously punctured; metepisternum horizontally striate on upper two-thirds, ventral third somewhat areolate. Basal area of propodeum strongly striate, posterior edge strongly imbricate; lateral surface rugose, ventrally with a few striae; posterior surface minutely reticulate, slightly nodulate and double-punctate, bigger punctures separated by about three times a puncture width, surface bordered by carinae. First metasomal tergum smooth except centrally with minute punctures separated by $2-4$ times a puncture width; terga two through four generally imbricate and punctate, small punctures separated by a puncture width; fifth tergum with punctures slightly larger and separated by about twice their width; sterna more strongly imbricate than terga, with scattered punctures on apical halves bearing setae.

Pubescence generally yellowish-white except brown setae on outer surfaces of tibiae and basitarsi. Face with yellowish, minutely-branched setae, such setae becoming shorter toward vertex, around antennal sockets, and paraocular areas; clypeal setae scattered centrally, fringelike on anteriormost margin; gena with setae like those of face; postgena with long setae more scattered than those of gena and becoming scarce near hypostomal area. Pronotal anterior and lower lateral areas with sparse, branched setae; pronotal dorsal surface along posterior margin connecting dorsolateral angles with appressed, dense, short setae with several branches arranged in rosettes. Mesoscutum with setae similar to those on face, setae becoming slightly shorter laterally; scutellar pubescence as on mesoscutum, with several short simple setae on central disc; metanotum covered with appressed, short, minutely-branched setae, setae more dense on anterior medial surface, with some scattered, long, minutely-branched setae. Pleura with setae like those on face, setae becoming longer and more simple ventrally (i.e., minute branches become gradually shorter and effectively disappear); metepisternum with setae like those on metathorax, with short, appressed setae concentrated along upper margin. Propodeal lateral surface with scattered, long, simple setae medially, becoming plumose along posterior border, with an arrangement of short, appressed setae covering anterior and lower posterior areas; posterior surface with short setae intermixed with scattered, long, branched setae. Metasomal terga densely covered with appressed, short, yellowish, setae, setae becoming longer laterally, except first metasomal tergum with anterior and lateral surfaces with long setae and scarce setae on disc; sternal setae long, erect, and with long branches, setae covering surface of second metasomal sternum and apical halves on remaining sterna; margins and gradular bases of sterna with medially-interrupted bands of short setae.

Male: Unknown.

Etymology. The specific epithet is taken from the type locality and is treated as a noun in apposition.

Type material. Holotype, GUATEMALA: female, Baja Verapaz, 17 km N. Salamá, Hwy [Highway] 5, 1700 m, 29 June 1993, R. Brooks, J. Ashe [collectors]. Deposited in the Division of Entomology, University of Kansas Natural History Museum. 


\section{Lasioglossum (Dialictus) oaxacacola sp. nov.}

Figures 1,8

Diagnosis. This species is most similar to L. verapaz (vide supra) but is slightly smaller and differs by the following features: mesoscutal punctures of central disc shallow but distinct and separated on otherwise strongly imbricate integument by a puncture width or less; coarse punctures of mesepisternum blend into strong dorsoventral striae (instead of areolate in $L$. verapaz); first metasomal tergum imbricate with minute punctures on posterior half separated by $1-2$ times a puncture width.

Description. As described for $L$. (D.) verapaz (vide supra) except as follows: Female: Total body length $6.65 \mathrm{~mm}$ (paratype $6.20 \mathrm{~mm}$ ); forewing length $5.09 \mathrm{~mm}$ (paratype $4.92 \mathrm{~mm}$ ). Head slightly broader than long, length $1.87 \mathrm{~mm}$ (paratype 1.80), width $2.05 \mathrm{~mm}$ (paratype $2.00 \mathrm{~mm}$ ). Upper interorbital distance $1.20 \mathrm{~mm}$ (paratype $1.16 \mathrm{~mm}$ ), lower interorbital distance $1.09 \mathrm{~mm}$ (paratype $1.08 \mathrm{~mm}$ ). Intertegular distance $1.53 \mathrm{~mm}$ (paratype $1.48 \mathrm{~mm}$ ). Mesoscutum contiguously and strongly punctured as on face except central disc strongly imbricate with shallow but distinct punctures separated by a puncture width or less (Fig. 8). Pre-episternum and mesepisternum coarsely and contiguously punctured on upper half, punctures blending into dorsoventral striae on ventral half and on venter. First metasomal tergum faintly imbricate with minute punctures on posterior half separated by 1-2 times a puncture width; remaining terga generally imbricate and punctate, small punctures separated by a puncture width or less.

Male: Unknown.

Etymology. The specific epithet is a combination of Oaxaca and the suffix "cola" meaning "residing in" and is a reference to the occurrence of the species in the State of Oaxaca.

Type material. Holotype female, "[MEXICO]: Oaxaca, Crawford [collector] // Collection of L. A. C. M. ex Pomona College, 1967". Paratype female, "[MEXICO]: Oaxaca, Crawford [collector] // Collection of L. A. C. M. ex Pomona College, 1967". Both specimens are located in the Los Angeles County Museum.

\section{Key to Species of the Aurora Group}

1. Metasoma metallic gold or brassy .2

- Metasoma dark metallic blue ………………………........... (D.) cyanorugosum n. $\mathrm{sp.}$

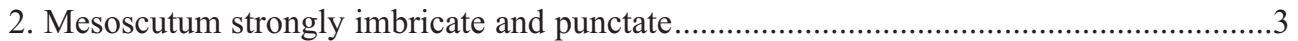

- Mesoscutum strongly rugose........................................................ (D.) aurora (Smith)

3. Central disc of mesoscutum with punctures shallow but distinct and separated by a puncture width or less; mesepisternum with dorsoventrally-oriented striae on ventral half and on venter; first metasomal tergum imbricate with minute punctures on posterior half separated by 1-2 times a puncture width..................................... (D.) oaxacacola $\mathrm{n}$. $\mathrm{sp}$. Central disc of mesoscutum with punctures faint and separated by a puncture width; mesepisternum with elongate areolae on ventral half and on venter; first metasomal tergum smooth with minute punctures centrally separated by $2-4$ times a puncture width L. (D.) verapaz n. sp. 


\section{ACKNOWLEDGEMENTS}

We are grateful to G. Else (NHML) for the loan of Smith's holotype and to R. R. Snelling (LACM) for permitting us to study material under his stewardship. Partial support for this study was provided by NSF EF-0341724 and DEB-0542909 (to MSE), and by a Guggenheim Fellowship from the John Simon Guggenheim Memorial Foundation (to MSE). Participation of the junior authors was made posible by fellowships from CONACYT (Consejo Nacional de Ciencia y Tecnología, México). This is contribution No. 3477 of the Division of Entomology, University of Kansas Natural History Museum.

\section{LITERATURE CITED}

Ayala, R., T.L. Griswold \& D. Yanega. 1996. Apoidea (Hymenoptera). Pp. 423-464. In: Llorente, J., A. N. García \& E. González (eds.), Biodiversidad, Taxonomía y Biogeografia de Artrópodos de México: Hacia una Síntesis de su Conocimiento. CONABIO-UNAM, México.

Cockerell, T.D.A. 1897. New and little-known bees. Trans. Amer. Entomol. Soc. 24: 144-162. 1905a. Notes on some bees in the British Museum. Trans. Amer. Entomol. Soc. 31:

309-364.

1905b. The halictine bees of the America. Amer. Nat. 39: 89-91.

1912. Descriptions and records of bees - XLVI. Ann. Mag. Nat. Hist., ser. 8 10: 311-320.

Engel, M.S. 2000. A new Lasioglossum from the Juan Fernandez Islands (Hymenoptera: Halictidae). Rev. Chilena Ent. 27: 5-10.

2001a. A monograph of the Baltic amber bees and evolution of the Apoidea (Hymenoptera). Bull. Amer. Mus. Nat. Hist. 259: 1-192.

2001b. Three new Habralictellus bee species from the Caribbean (Hymenoptera: Halictidae). Solenodon 1: 33-37.

Engel, M.S., R.W. Brooks \& D. Yanega. 1997. New genera and subgenera of augochlorine bees (Hymenoptera: Halictidae). Sci. Papers, Nat. Hist. Mus., Univ. Kansas 5: 1-21.

Hinojosa-Díaz, I.A. 2003. A new Lasioglossum from Mexico, with the discovery of the male for L. xyriotropis (Hymenoptera: Halictidae). J. Kansas Entomol. Soc. 76(1): 47-54.

Hinojosa-Díaz, I.A. \& M.S. Engel. 2003. Megalopta (Noctoraptor) furunculosa sp. n., a new nocturnal, cleptoparasitic bee from Guyana (Hymenoptera: Halictidae). Folia Heyrovskyana 11(3-4): 137-141.

McGinley, R.J. 2003. Studies of Halictinae (Apoidea: Halictidae), II: Revision of Sphecodogastra Ashmead, floral specialists of Onagraceae. Smithsonian Contrib. Zool. 610: 1-55.

Moure, J.S. \& P.D. Hurd, Jr. 1987. An Annotated Catalog of the Halictid Bees of the Western Hemisphere (Hymenoptera: Halictidae). Smithsonian Institution Press; Washington, D.C. vii+405 pp.

Smith, F. 1879. Descriptions of New Species of Hymenoptera in the Collection of the British Museum. Taylor and Francis; London, UK. xxi+240 pp.

Vachal, J. 1904. Halictus nouveaux ou présumés nouveaux d'Amérique (Hymenoptera). Bulletin de la Société Scientifique, Historique et Archéologique de la Corrèze 26: 469-486.

Recibido: 23 de mayo de 2006

Aceptado: 15 de junio de 2007 